\title{
TranS I VEO system: a novel psoas-sparing device for transpsoas lumbar interbody fusion [Corrigendum]
}

\author{
Hardenbrook MA, Miller LE, Block JE. Medical Devices: \\ Evidence and Research. 2013;6:91-95. \\ On page 94, the disclosure was listed as "LEM and JEB \\ received financial support from TranS1 Inc for assistance with \\ manuscript development. MAH reports no conflict of interest \\ in this work." in error. The disclosure should have been \\ "LEM and JEB received financial support from TranS1 Inc \\ for assistance with manuscript development. MAH receives \\ a royalty for the VEO system, in addition to other payments \\ for consulting/training work performed."
}

\section{Publish your work in this journal}

Medical Devices: Evidence and Research is an international, peerreviewed, open access journal that focuses on the evidence, technology, research, and expert opinion supporting the use and application of medical devices in the diagnosis, treatment and management of clinical conditions and physiological processes. The identification of novel devices and optimal use of existing devices which will lead to improved clinical outcomes and more effective patient management and safety is a key feature. The manuscript management system is completely online and includes a quick and fair peer-review system. Visit http://www. dovepress.com/testimonials.php to read real quotes from authors. 